\title{
Development and Assessment of Key Skills in Undergraduate Students: An Action-Research Experience
}

\author{
Ana Fernández-Santander ${ }^{a,}{ }^{*}$, María José García-García ${ }^{a}$, Beatriz Sáez-Pizarro ${ }^{a}$, and \\ María José Terrón-López ${ }^{a}$ \\ a Universidad Europea de Madrid, Spain
}

\begin{abstract}
Employers look for professionals able to work in a team, able to approach problems, with the capacity to analyze and resolve problems, under the constant renewal of knowledge and competencies. In this paper, a group of University teachers from different areas of knowledge presents an experience to introduce key employability skills in the higher education students' curricula. This work has been developed under the action research scope. The first goal was to make an analysis of terms referred to key skills, generating an integrated denomination for each competency. The elaboration of general templates for key skills is proposed here as a useful tool that provides information about development, assessment and marking of each skill. Different types of rubrics and assessment templates, used during this experience, are presented.
\end{abstract}

Keywords: assessment, descriptive templates, key skills, professionals, rubrics, teachers

\section{Introduction}

The Bologna process aims to create a European Higher Education Area (EHEA) by 2010 (The Bologna Process 2009). All across Europe, countries and universities, are engaged in a modernization's process. Therefore, a great transformation must be assumed from the point of view of the educational management as well as the intervention in the classrooms.

The first consequence of the Bologna declaration is the valuation of each course through the European Credit Transfer System (ECTS) (2009), which is based on the student workload required to achieve the objectives of a programme, in terms of the learning outcomes and competences to be acquired. As Spencer and Spencer (1993) have shown, 'the better the fit between the requirements of a job and the competences of a person, the higher the person's job performance and job satisfaction will be'.

The second consequence of Bologna involves a great challenge: the formation must be tied with the professional demands by means of the development and assessment of the key skills (Fallows and Steven 2000). In Harvey et al. (1997) we found that employers want people who are going to be effective in this future, changing world. The employees must be flexible, adaptable, quick to learn and able to deal with change. They must be people who can rapidly adapt themselves to the workplace culture, take on responsibility for an area of work, and perform efficiently and effectively. Therefore, necessary changes in teaching must be carried out, but these changes cannot be done without the coordination of the implied staff (Rodríguez 2003; Zabalza 2000; Terrón et al. 2007; Learreta et al. 2006). We must therefore prepare students

* Corresponding author (ana.fernandez@uem.es)

Suggested citation: Fernández-Santander, A., García-García, M. J., Sáez-Pizarro, B., \& Terrón-López, M. J. (2012). Development and assessment of key skills in undergraduate students: an action-research experience. Higher Learning Research Communications, 2(1), 32-49. http://dx.doi.org/10.18870/hlrc.v2i1.37 
to engage in the issues of nowadays which means that young people must be able to work in interdisciplinary works (Boix Mansilla et al., 2000, 2007, 2009; Boix Mansilla, 2005, 2006).

As a result, the first scope of the work developed was firstly to make a literature review about key skills development in other universities than the Spanish ones in order to find a way to help our teachers to understand how to integrate key skills in the new degrees.

In that sense a group of the academic staff at the Universidad Europea de Madrid (UEM) was created to generate some research about the new needs (Terrón et al. 2007). In this paper, we describe how we began to engage and make sense to the integration of key skills in different curricula. This was done under the scope of the new active teaching - learning methods and strategies within the approach EHEA.

The action-research methodology was followed (identification of a problem, consideration of different alternatives of action, taking an action and study of its consequences, making a critical reflection about them, review the actions and start again). That is, from the team reflection of the researchers we found results from whose analysis we took some actions to improve. So, each time that the researchers' team made an action, a readjustment of the initial plan took place from its reflection and helped by all the experiences of the group.

\section{Developing a Curriculum Integrating Key Skills for New Degrees}

In recent surveys done to employers is found that they were looking for applicants who can communicate effectively, can work in teams, with good interpersonal skills, can solve problems, are flexible in their approach to work and so far (Ellis et al., 2004; Spencer \& Spencer, 1993; Harvey et al., 1997). In spite of these surveys and of other studies and reports about the need of integrating the competences in higher education (Fallows \& Steven 2000), it is well known that the university tradition is mainly academic. Traditionally in Spain, the academic staff has developed in their students some skills or competences (oral and written communication, team working, planning and problem solving, etc.) without being aware of it, without a previous planning neither a curriculum integrated approach and, by no means, an assessment and marking criteria. In response to employer expectations, Spanish universities are now focusing on development of generic skills in their new degrees' curricula. Taking into account that graduates will enter into a competitive and fast-moving job market, educational institutions have the duty of transfer not only knowledge but also skills demanded from employers. In this way, many universities are proposing specific skills in every degree to be implemented in the context of the European Higher Education Area (EHEA). Communication skills, problem solving, working with others, information technology among others are some of the main key skills areas recognized by University of Salford -Manchester- educationalists according to employers' interviewers (Key Skills in the University of Salford, 2009). The University of Nottingham is also working in the evaluation of key skills from the employer perspectives. They combine qualitative and quantitative research methods to include a review of key skills identified by professional bodies relevant to the different subject areas. One of their aims is to identify which skills are actually developed and which methods have been used for their development. Analytical and problem solving, team working and self-learning were some of the main skills developed (Ellis et al., 2004).

The main aim of this paper is to design the key skill curriculum adapted to new degrees in order to identify the key skills that employers desire from new graduates and to propose effective and easy tools to assess them. The first difficulty found was the lack of single, 
universally accepted names for each key skill to be developed, so a work of theoretical framework should be done. Therefore, we referred to several sources. First of all, it was consulted the skills included in the Tuning Educational Structures in Europe Project (González \& Wagenaar, 2003) as well as Developing Skills in Healthcare (2009), in Oliver and Sanz (2007) and the work developed in the DeSeCo project (Rychen \& Salganik, 2001, 2003; Salganik \& Rychen, 1999; Rychen et al., 2003). Secondly, it was made a revision of the collegiate skills that appeared at the UEM Delphi project report (INFORME DELPHI: "Detection of skills asked by the employers in the new graduates", 2001). Finally, official resources from Spanish Education and Science Ministry were consulted (Real Decreto 1393/2007, Orden ECI/332/2008, Real Decreto $55 / 2005$ ) as well as studies made by others universities. For example, the Nelson Report (Nelson 2002), Employability Skills for the Future and the University of Sidney Reports (1997, 2000, 20002004, 2002a, 2002b, 2003a, 2003b) in Australia; the Bennett, Dunne and Carré report (2000) in UK and many UK university studies like the report. An institutional approach to developing students' transferable skills (Atlay and Harris 2000), the Embedding Key Skills within a Traditional University project, funded by the DfEE (Chapple \& Tolley, 2000).

Weekly meetings of the research team were done under the action-research scope. From the reasoned discussions among researchers the main competences that UEM students must develop were decided, taking into account all the references detailed in the paragraph above.

Table 1 shows the consensus skill names adopted in our research group as we were pretending to adopt a unique denomination to avoid misunderstandings between the academic staff. It is important to note that the second column refers to what we called "other names" that was the names that appear in the bibliography sources consulted. Sometimes these "other names" refer to a developed competency level of the consensus one. We could say in these cases, that the consensus will be for a global aspect of the others.

In the next paragraphs, it will be analyzed how these chosen skills have been developed and assessed in EHEA degrees.

Table 1. List of Adopted Key Skills Denomination.

\section{Consensus Key Other Names Found in the References \\ Skills Names}

Ability to adapt oneself to new situations

Awareness of ethical values
Versatility to adapt oneself to new situations. Resistance and adaptation to the environment. Flexibility.

Ethical sense (ethic and ethical commitment).

Ethical commitment.

Ethics and values.

Ability to understand the ethical responsibility and professional deontology.

Ethics and professional responsibility.

Ethical principle/respect.

Incorporation of ethical and legal values.

To understand the ethical implications.

Ethical Sense. 


\begin{tabular}{|c|c|}
\hline Independent Learning & $\begin{array}{l}\text { Ability to learn. } \\
\text { Ability to quickly acquire new knowledge. } \\
\text { Ability to work autonomously. } \\
\text { To have skills for lifelong learning, self-directed and autonomous. } \\
\text { Ability to improve and update knowledge and acquired abilities. } \\
\text { Self-learning of new skills and techniques. } \\
\text { Orientation to learning. } \\
\text { High degree of autonomy. }\end{array}$ \\
\hline $\begin{array}{l}\text { Planning and time } \\
\text { management }\end{array}$ & $\begin{array}{l}\text { Capacity of organization and planning. } \\
\text { Ability to use time effectively. } \\
\text { Capacity of planning, management and control. }\end{array}$ \\
\hline Problem solving & Ability to find new ideas and solutions. \\
\hline $\begin{array}{l}\text { Information management } \\
\text { (search, selection and } \\
\text { integration) }\end{array}$ & $\begin{array}{l}\text { Abilities of information management (ability to find and analyze } \\
\text { information from various sources). } \\
\text { Gather and interpret relevant data. } \\
\text { Collection and analysis of information. } \\
\text { Information management ability (ability to find and analyze } \\
\text { information from several sources). }\end{array}$ \\
\hline Critical thinking & $\begin{array}{l}\text { Critical capacity and self-criticism. } \\
\text { Arguments making and assertion. } \\
\text { To deliver judgments that include reflect on relevant social, scientific } \\
\text { or ethical issues. } \\
\text { Willingness to enquire about own and other's ideas. Critical point of } \\
\text { view. } \\
\text { Critical and reflexive thinking. }\end{array}$ \\
\hline Team working & $\begin{array}{l}\text { Learning and collaborative work. } \\
\text { Ability to work in teams. } \\
\text { To work in uni-, multi- and inter-disciplinary teams. } \\
\text { Ability to work in an interdisciplinary team. } \\
\text { Ability to work in an international context. }\end{array}$ \\
\hline Self-confidence & Confidence in his/her own judgement. \\
\hline $\begin{array}{l}\text { Ability to apply knowledge } \\
\text { to practice }\end{array}$ & To apply their knowledge to their work. \\
\hline $\begin{array}{l}\text { Oral Communication. } \\
\text { Written } \\
\text { Communication }\end{array}$ & $\begin{array}{l}\text { Oral and written communication in their mother tongue. } \\
\text { Ability to transmit information, ideas, problems and solutions. Ability to } \\
\text { present in results, ideas or reports. } \\
\text { Ability to write reports or documents. Ability to make themselves } \\
\text { understood. } \\
\text { Oral and written communication in the mother tongue. } \\
\text { Ability to know how to communicate (in an oral and in a written way). } \\
\text { Ability to write. } \\
\text { Ability to communicate writing and orally, knowledge, procedures, } \\
\text { results and ideas. } \\
\text { To Communicate effectively and clearly both orally and writing. Written } \\
\text { and verbal communication. } \\
\text { Interpersonal Communication. }\end{array}$ \\
\hline
\end{tabular}

Responsibility

Decision-making

Decision-making (judgement capacity). Ability to make decisions. 
Initiative and entrepreneurial spirit

Use of information, communications and technology (ICT)

Skills in the interpersonal relations
Initiative. Ability to identify new opportunities.

Entrepreneurial spirit.

Basic skills of the computer use.

Ability to use computer tools.

Computer knowledge in the field of study.

ICTs use.

Interpersonal understanding.

Interpersonal skills.

Social interaction (human relations capacity, interpersonal relations and relationship capacity). Interpersonal communication.

Social skills.

Innovation and creativity

Ability to find new ideas and solutions. Creative thinking. Creative point of view. Ability to generate new ideas (creativity).

\section{Looking for Practical Teaching and Learning Resources to Develop Key Skills: The Templates}

With the key skills that should be developed in a degree student in mind, each teacher thought about its actual development and possible proposals for improvement from their own subjects' perspective. This work carried out a clearer definition of their descriptors, expectations and implementation. Our aim was to create a general template for all the key skills in order to provide a useful tool to academic staff with the skills development, assessment and marking. The previous experience gained on its implementation (Learreta et al., 2006; García et al., 2008) has been enhanced to provide both, the student and the teacher, the information needed in a more integrated and easy way to be handled.

To fulfill these templates, we thought about three questions: how to implement the key skills; which activities can be done to promote them; how to take an assessment and marking criteria. For every skill we look for proposing learning resources as handouts, worksheets, checklists and assessments guides which staff could use or adapt, as well as material about the skills and their development. The general organization of each template is like the example shown in table 2. It has been divided in five main sections: name, definition, development, assessment and references. It is very important to include in each worksheet a cell containing the references used to fulfill it.

\section{Name of the Skill}

The first argument shows the consensus name adopted among researchers and the next one other names included, as shown in table 1 in previous section. It must be remembered that it is very important that all the teachers of a degree use the same nomenclature for a given skill in order to avoid misunderstandings.

\section{Definition of the Key Skill}

This section covers what is necessary to understand the key skill, that is, the definition, the description, the required skills and other key skills that are developed from this one (table 2).

The definition has been taken from the literature we found about it. The description is the most important part of the worksheet. It provides both the student and the teacher, all the 
information they need to understand the competency. Looking at this list, they will know what they need to develop this skill and therefore what should be assessed. By giving a description of the skill, the academic staff and the students know which capacities they will develop throughout the course. It doesn't mean that all the skills must be integrated in all the subjects, but from the collegiate action of the academic staff an optimal level of development of every skill must be acquired when they finish the degree. It is very important to indicate the relationship among the skills due to their cross-curricular theme. That is why it must be included in this section which key skills are needed to develop it (required key skill) and what competences will be developed from it.

\section{Key Skill Development}

Once the skill is defined, there are some changes needed in teaching methodologies to strengthen the development of workplace skills. The use of some learning methods and educational strategies (such collaborative learning, problem based learning, project based learning and case studies methodology) is very adequate to develop this kind of skills, but it is a hard change for teachers and implies a strong effort on coordination. The simplest way to develop that change gradually is to include in each subject some learning activities that facilitate key skill development.

In that way, some teaching and learning short resources for each skill are given at each worksheet. Let us remark that the first activity proposed is a briefing about the skill where the lecturer will explain the meaning of the generic skill, which activities could be done to implement it and how it would be assessed. The objective of this first activity is to put the pupil in the context of what is the "key skill activity". Then a wide range of learning activities is proposed to develop that generic key skill. Teachers will choose from this list those they consider more suitable for their subject or maybe they will propose some others.

\section{Key Skill Assessment}

In this section essential information about the assessment is given (the indicators, the procedures and the tools) so the acquisition of the key skill level can be measured. The indicators must be adapted to each subject according to the program it is integrated and its characteristics. These indicators establish what will be assessed for each key skill. They will be given as list of specific items more focused to the assessment than those mentioned in the description. The indicators must be SMART, that is Specific, Measurable, Achievable, Relevant and Time of completion, but they can be both quantitative and qualitative. Rate of done activities, rate of attendance team work session or results in peer-assessment are some of the indicators that can be used as it can be seen in table 2 .

In order to measure the skill level acquired by the student with validity a series of procedures must be given as, for instance, observational techniques, per appraisal and selfreport procedures. From the list given, the teacher can use a combination of assessment procedures always estimating their validity, reliability and fairness for each activity. Finally, several assessment tools are proposed in order to help the teachers to mark these activities avoiding the own subjectivity of the general skills. 
Table 2. Team Working Worksheet.

\section{Name of the Key Skill:}

\begin{tabular}{ll}
\hline Consensus name & Team working \\
\hline Other names & $\begin{array}{l}\text { Teamwork } \\
\text { Cooperative work Team management Interdisciplinary } \\
\text { teamwork Collegiate thinking }\end{array}$ \\
\hline Definition of the Key Skill: & \\
\hline
\end{tabular}

Definition

Description

Required skills

Other key skills develop from this key skill
Ability to integrate and collaborate actively with other people, areas and / or organizations to achieve common goals.

- To identify oneself with a common project

- To Participate and collaborate actively in the team tasks

- Including everyone and own ideas

- Encouraging everyone's contributions

- To work collaboratively with different groups, identify the needs of others and build positive relationships, develop cooperative learning strategies

- Offering facts, opinions, ideas, suggestions and relevant information and share them with the group

- Warmly encouraging participation from all group members, clearly values and accepting contributions

- To work towards a common goal

- To work beyond individual accomplishments assuming the appropriate role within the group

- To encourage the discussion

- To admit others achievements

- To be able to assume the mistakes made by the other team members

- To share rights and responsibilities

- To try to maintain harmony among the team members

- Responsibility

- Skills in interpersonal relations

- Planning and time management

- Oral and written communication

- Information management

- Problem solving

- Decision making

- Critical reasoning

- Ability to adapt to new situations

- Initiative and Entrepreneurial spirit 


\section{Key skill development:}

Learning activities to develop the skill
- Briefing on key skill, its development and assessment

- Cooperative work guided by the professor

- Collaborative work

- Peer training lessons in laboratory

- Research teamwork

- Oral presentation in public

- Cases team Resolution

- Discussions

- Information Management in group

\section{Key Skill Assessment:}

Indicators

Assessment procedures

Assessment procedures
- Rate of done activities in group

- Rate of attendance to the group sessions

- Overcomes got by the team members assessment

- Results at the teamwork performance

- Reader's supervision of the teamwork process

- Reader's supervision of each individual contribution

- Accomplished of meeting records

- Making records of group meetings (daily work, route sheets, etc.)

- Self-assessment of own contributions to team work Coevaluation about the other members' contributions

- Professor's assessment of each member of group

- Analysis and assessment of the behaviour of the group

Assessment tools

- Individual and group interviews for feedback

- Meeting record worksheet specifying each member contribution

- Control lists attendance

- Co-evaluation and self-assessment template or rubric

- Template/rubric for the performance by the teacher

\section{References:}
References used
Alles M., 2005
Benito A. et al., 2005
Fallows S. \& Steven C., 2000
García M.J. et al., 2007
Katzenbach Jr. \& Smith Dk., 1993
Poblete, M. \& García A., 2007
Villa A. \& Poblete M., 2007
Rubistar, Rubric ID=1363820
Rubistar, Rubric ID= 1094287 


\section{Tools for Key Skill Assessment}

There is no doubt about the difficulty of creating procedures and tools to assess and mark the skill level acquired by the students. When it was possible, rubrics were made with the help from our previous teaching experiences (García et al., 2010; Terrón et al., 2009a, 2009b; Blanco et al., 2007) and some Internet resources as, for instance, www.rubrics.org, so marking the students became easier for the teacher. The teacher has always to have in mind that rubrics should be used mixed with other methods of assessment ("as long as the rubric is only one of several sources, as long as it doesn't drive the instruction, it could be conceivably play a constructive role", in Kohn 2006). We proposed a long list of items for each skill in order to cover a wide range of possible situations and subjects, so the teacher will be able to choose the items more suitable for each activity. Table 3 shows some indicators of the oral and written communication skills that could be measured. For each indicator, four different situations were described in order to make easier the assignation of a record from 1 (never) to 4 (always).

Table 3. Rubric to Assess Oral and Written Communication

\begin{tabular}{|c|c|c|c|c|c|}
\hline & INDICATORS & 4 & 3 & 2 & 1 \\
\hline \multirow{4}{*}{ 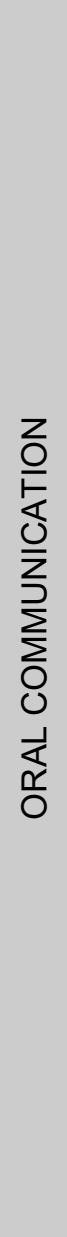 } & \multirow[t]{2}{*}{ Vocabulary } & $\begin{array}{l}\text { Uses always the } \\
\text { adequate } \\
\text { vocabulary } \\
\text { (scientific, } \\
\text { technical, ...) to } \\
\text { the subject. }\end{array}$ & $\begin{array}{l}\text { Uses frequently } \\
\text { the adequate } \\
\text { vocabulary } \\
\text { (scientific, } \\
\text { technical, ...) to } \\
\text { the subject. }\end{array}$ & $\begin{array}{l}\text { Uses poorly the } \\
\text { adequate } \\
\text { vocabulary } \\
\text { (scientific, } \\
\text { technical, ...) to } \\
\text { the subject. Its } \\
\text { language is very } \\
\text { colloquial. }\end{array}$ & $\begin{array}{l}\text { Doesn't use the } \\
\text { adequate } \\
\text { vocabulary } \\
\text { (scientific, } \\
\text { technical, ...) to } \\
\text { the subject. Its } \\
\text { language is very } \\
\text { colloquial. }\end{array}$ \\
\hline & & $\begin{array}{l}\text { Speaks correctly } \\
\text { without using } \\
\text { postscripts or } \\
\text { filler word. }\end{array}$ & $\begin{array}{l}\text { Speaks correctly } \\
\text { but uses } \\
\text { sometimes } \\
\text { postscripts. }\end{array}$ & $\begin{array}{l}\text { Speaks correctly } \\
\text { but uses a lot of } \\
\text { postscripts. }\end{array}$ & $\begin{array}{l}\text { Speaks using a } \\
\text { lot of postscripts } \\
\text { and not correctly. }\end{array}$ \\
\hline & $\begin{array}{l}\text { Presentation } \\
\text { format }\end{array}$ & $\begin{array}{l}\text { The presentation } \\
\text { has got an } \\
\text { adequate format } \\
\text { (not too much } \\
\text { text and enough } \\
\text { figures). }\end{array}$ & $\begin{array}{l}\text { The presentation } \\
\text { has got an } \\
\text { adequate format } \\
\text { but can be } \\
\text { improved on the } \\
\text { text and on the } \\
\text { amount of } \\
\text { figures. }\end{array}$ & $\begin{array}{l}\text { The presentation } \\
\text { has got too much } \\
\text { text and few } \\
\text { graphics or figures } \\
\text { to illustrate it. }\end{array}$ & $\begin{array}{l}\text { There is too much } \\
\text { text (small letter } \\
\text { size, difficult to be } \\
\text { read), and no } \\
\text { figures or } \\
\text { graphics to } \\
\text { illustrate it. }\end{array}$ \\
\hline & $\begin{array}{l}\text { Contents } \\
\text { Structure }\end{array}$ & $\begin{array}{l}\text { The document } \\
\text { contents are } \\
\text { clear and well } \\
\text { focalised to the } \\
\text { subject. }\end{array}$ & $\begin{array}{l}\text { Most of the } \\
\text { document content } \\
\text { is clear and well } \\
\text { focalised to the } \\
\text { subject. }\end{array}$ & $\begin{array}{l}\text { A small part of the } \\
\text { document contents } \\
\text { is clear and well } \\
\text { focalised to the } \\
\text { subject. }\end{array}$ & $\begin{array}{c}\text { The document } \\
\text { contents are not } \\
\text { clear and are not } \\
\text { focalised to the } \\
\text { subject. }\end{array}$ \\
\hline
\end{tabular}




\begin{tabular}{|c|c|c|c|c|c|}
\hline & INDICATORS & 4 & 3 & 2 & 1 \\
\hline \multirow{5}{*}{ 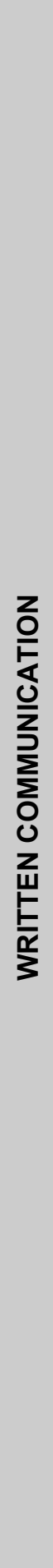 } & Spelling & $\begin{array}{l}\text { The document is } \\
\text { written with correct } \\
\text { spelling. }\end{array}$ & $\begin{array}{l}\text { The document is } \\
\text { written with } 2 \text { or } 3 \\
\text { spelling errors. }\end{array}$ & $\begin{array}{l}\text { The written } \\
\text { document } \\
\text { containing } 3 \text { or } 4 \\
\text { misspellings. }\end{array}$ & $\begin{array}{l}\text { The written } \\
\text { document } \\
\text { contains } \\
4 \text { or more } \\
\text { misspellings. }\end{array}$ \\
\hline & Vocabulary & $\begin{array}{c}\text { Writer uses a } \\
\text { proper vocabulary. } \\
\text { He communicates } \\
\text { strongly or } \\
\text { captures the } \\
\text { reader's interest. }\end{array}$ & $\begin{array}{l}\text { The words } \\
\text { selected are } \\
\text { adequate, but } \\
\text { one word is } \\
\text { constantly } \\
\text { repeated. }\end{array}$ & $\begin{array}{l}\text { Writer uses a } \\
\text { limited vocabulary. } \\
\text { There are two or } \\
\text { three words } \\
\text { repeated } \\
\text { constantly. }\end{array}$ & $\begin{array}{l}\text { Writer uses a } \\
\quad \text { limited } \\
\text { vocabulary, and } \\
\text { very repetitive, } \\
\text { that does not } \\
\text { communicate } \\
\text { strongly or } \\
\text { capture the } \\
\text { reader's interest. }\end{array}$ \\
\hline & $\begin{array}{l}\text { Presentation } \\
\text { Format }\end{array}$ & $\begin{array}{l}\text { The format is } \\
\text { adequate (same } \\
\text { letter size, } \\
\text { interspacing, } \\
\text { justification, the } \\
\text { figures have got } \\
\text { title; the tittles } \\
\text { have got the same } \\
\text { format, etc.). }\end{array}$ & $\begin{array}{l}\text { The format } \\
\text { present } \\
\text { at least two errors } \\
\text { in its format } \\
\text { (same letter size, } \\
\text { interspacing, } \\
\text { justification, the } \\
\text { figures have got } \\
\text { title; the tittles } \\
\text { have got the } \\
\text { same format, } \\
\text { etc.). }\end{array}$ & $\begin{array}{c}\text { The format present } \\
\text { three or four errors } \\
\text { in its format (same } \\
\text { letter size, } \\
\text { interspacing, } \\
\text { justification, the } \\
\text { figures have got } \\
\text { title; the tittles } \\
\text { have got the same } \\
\text { format, etc.). }\end{array}$ & $\begin{array}{l}\text { The format } \\
\text { present } \\
\text { more than four } \\
\text { errors in its } \\
\text { format (same } \\
\text { letter size, } \\
\text { interspacing, } \\
\text { justification, the } \\
\text { figures have got } \\
\text { title; the tittles } \\
\text { have got the } \\
\text { same format, } \\
\text { etc.). }\end{array}$ \\
\hline & Contents & $\begin{array}{l}\text { The content of the } \\
\text { document is clear } \\
\text { and focused } \\
\text { according to the } \\
\text { subject. }\end{array}$ & $\begin{array}{l}\text { Most of the } \\
\text { document is clear } \\
\text { and focused } \\
\text { according to the } \\
\text { subject. }\end{array}$ & $\begin{array}{l}\text { Very little of the } \\
\text { content of the } \\
\text { document is clear } \\
\text { and focused to the } \\
\text { subject. }\end{array}$ & $\begin{array}{l}\text { The content of } \\
\text { the } \\
\text { document lacks } \\
\text { clarity and focus. }\end{array}$ \\
\hline & Organization & $\begin{array}{l}\text { The work is } \\
\text { properly structured } \\
\text { in sections. It has } \\
\text { introduction, } \\
\text { conclusion and } \\
\text { bibliography }\end{array}$ & $\begin{array}{l}\text { The work is well } \\
\text { structured into } \\
\text { sections but lacks } \\
\text { one of these } 3 \\
\text { sections: } \\
\text { introduction, } \\
\text { conclusions and / } \\
\text { or bibliography. }\end{array}$ & $\begin{array}{l}\text { The work is } \\
\text { divided into } \\
\text { sections but } \\
\text { contains only } 1 \text { of } \\
\text { these } 3 \text { sections: } \\
\text { introduction, } \\
\text { conclusions and / } \\
\text { or bibliography }\end{array}$ & $\begin{array}{l}\text { The work is } \\
\text { poorly structured } \\
\text { and lacks of } \\
\text { introduction, } \\
\text { conclusion and } \\
\text { bibliography }\end{array}$ \\
\hline
\end{tabular}


When the elaboration of rubric as the one showed at table 3 was too hard to create for some specific skills, a simpler one was made where the records were only "yes" or "no". Table 4 shows an example of a rubric type $y / n$ for the responsibility assessment. This template displays several particularities. Some aims are involved on it. On the one hand, the student's point of view about the suitability of the activity to the learning process is gathered. On the other, we try to get student to think about his own learning process and has got an initial idea of his mark. This template could be of compulsory deliver for the students for each activity done (group or individual).

Table 4. Template for Responsibility Assessment.

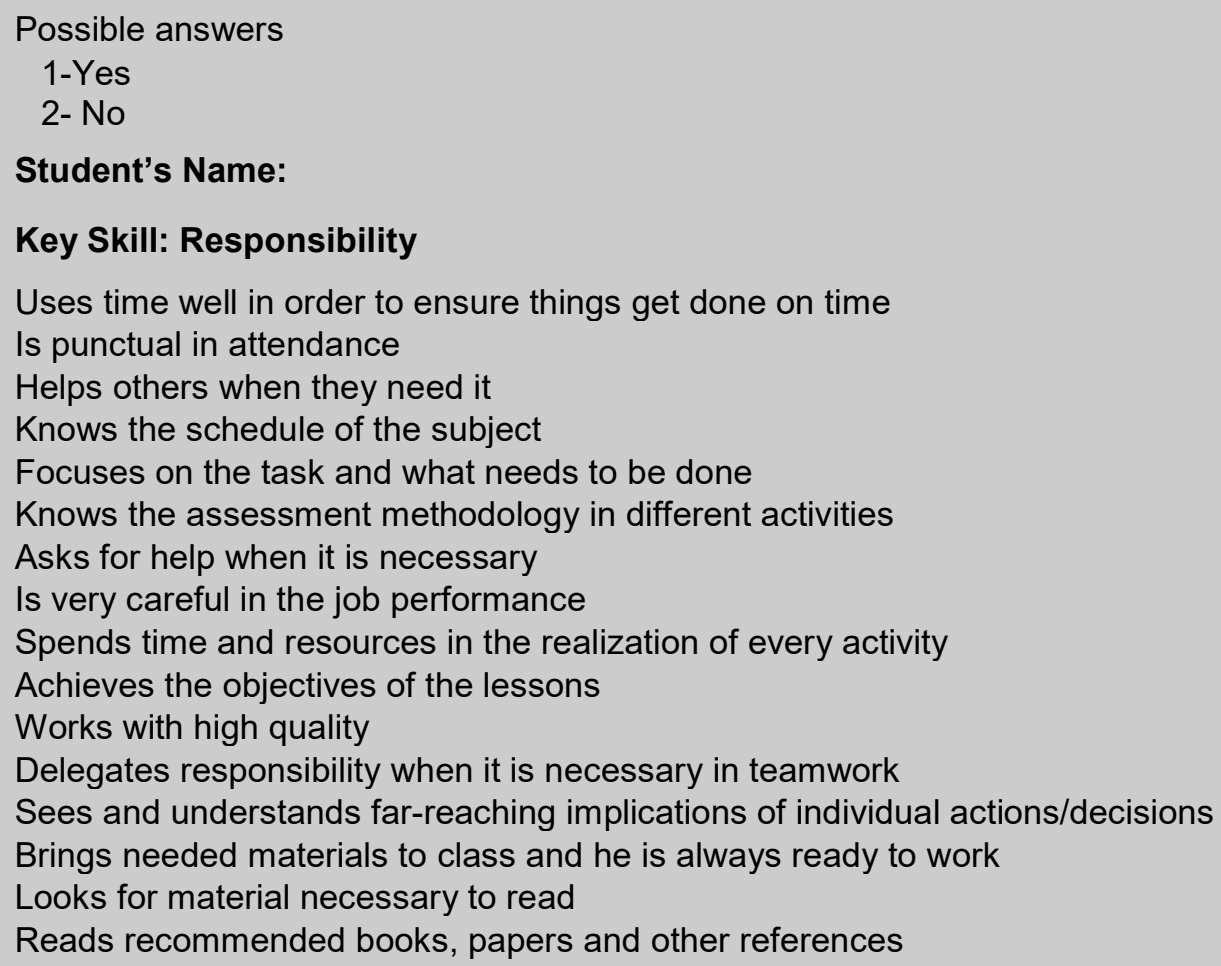

Another type of broader template is given in table 5. Each indicator or descriptor must be marked using a rating scale from 1 to 4 (1-never, 2-sometimes, 3-almost always, 4-always) according to the skill level acquired by the student.

All the assessments templates (tables 3, 4 and 5) could be used for each activity by the student individually (self-assessment), by peers (peer-assessment) and/or by the supervisor teacher. The staff can therefore adapt them to their courses, choosing the best indicators for the activity done. The final mark for the skill will be the average obtained. All of them have been used by teachers of different subjects and degrees at the Universidad Europea de Madrid with very good results (García et al., 2010).

The process to evaluate is a bit different when the students work in teams. The evaluation template will be filled after each session. It will be done first individually at home, making a selfassessment and an assessment to the other team members in an anonymous way. In the next team session, the group will collegiate an assessment for each member and for the team as a whole. Three marking will be obtained in this way (individual, collegiate and team self- 
assessment), and the staff will be the responsible to assign the weight of each item in the final mark. We must emphasize the importance of acting on the feedback on the teamwork. That is, the reader would ask the team to detect difficulties and areas of improvement, to enumerate positive aspects of the teamwork done and to find possible improvements to be made in the next sessions.

Table 5. Template for Team Working Assessment.

\section{Rating scale that can be used 1-never / completely disagree \\ 2-sometimes / disagree \\ 3-almost always / agree \\ 4-always / completely agree}

\section{Student's Name:}

\section{Shows respect for others}

The team member actively listens to others

There is a full participation in the elaboration of a job planning The team member prevents working separately or competitively The team member understands and values the opinion of others Integrates everyone in the group to have a full participation Informs the group of everything

The discussion moved forward with succeeding points building on previous ones

Shares information from research or experience

Works in a cooperative way

Understands and agrees on goals and objectives

Asks for ideas and opinions in order to solve problems and make decisions

Member resources are fully recognised and utilised

Avoids dominant attitudes

The team experiments with different ways of doing things and is creative in its approach

Acts with tolerance

Communication between members is open and participative

Encourages group interaction

Maintains a positive atmosphere

There are effective procedures to guide team functioning. Supports the procedures to teamwork Does public recognition of the others good work

Realizes that the job could not be done without the cooperation and contribution of everyone else

Gives preference to the group objectives before the own ones

There is full participation in leadership: leadership roles are shared by the members Structures and organizes well the ideas and communicates them effectively to the others Explains the others his individual job

There is high degree of trust among members and conflict is dealt with openly and worked through Is involved and compromise in the accomplishment of his/her tasks

Disagreements did not arouse defensive reactions

Assumes the job done (well or bad done)

Participates actively in the fair distribution of jobs not done in the session and brigs it later

The group often evaluates its functioning and processes 


\section{First Assessment Experiences Done}

The rubrics and assessment templates generated through this work have been implemented in some subjects. The information was collected just after each activity in order to have a quick feedback of the skill development. In this way, activities and assessment methods could be adapted to improve them. Results were collected in different ways: written reports excel files or using on-line platforms like moodle questionnaires (www.moodle.com). In most cases we tried to collect the results on-line, due to the advantages arisen from processing the data on a computer (statistics, graphics, etc.). The tools developed through this work can be used for self-evaluation, peers-evaluation as well as the evaluation made by the teacher. Students of the same subject (Fundamentals of Programming) in two different engineering degrees (Computer and Telecommunication) were involved the experience presented in this paper. Different activities were proposed to the students to work in team. Each team was formed by three students who had to solve several problems. An anonymous peer-evaluation was developed after these activities: each team member had to assess his/her partners anonymously. For it, they had to fill three templates for each skill assessed: Oral and Written Communication (Figure 1), Responsibility (Figure 2) and Team working (Figure 3).

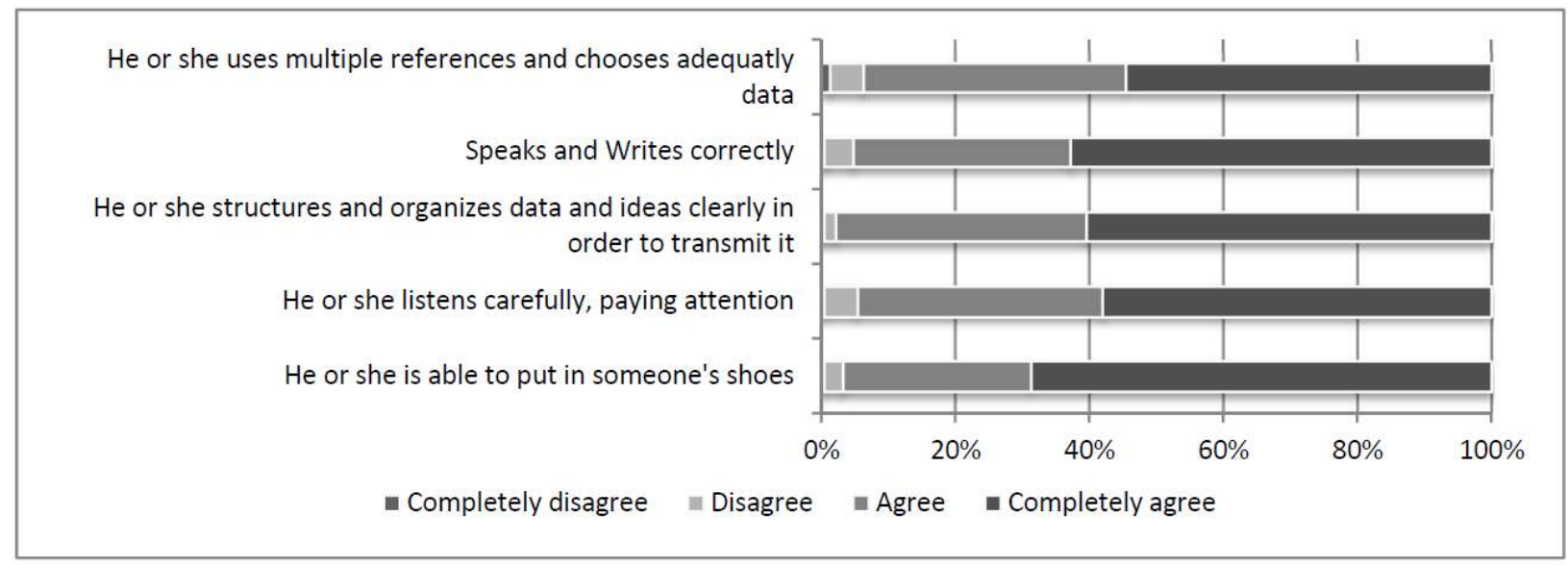

Figure 1. Peer-evaluation results for the oral and written communication skill ( $\mathrm{n}=107$ students).

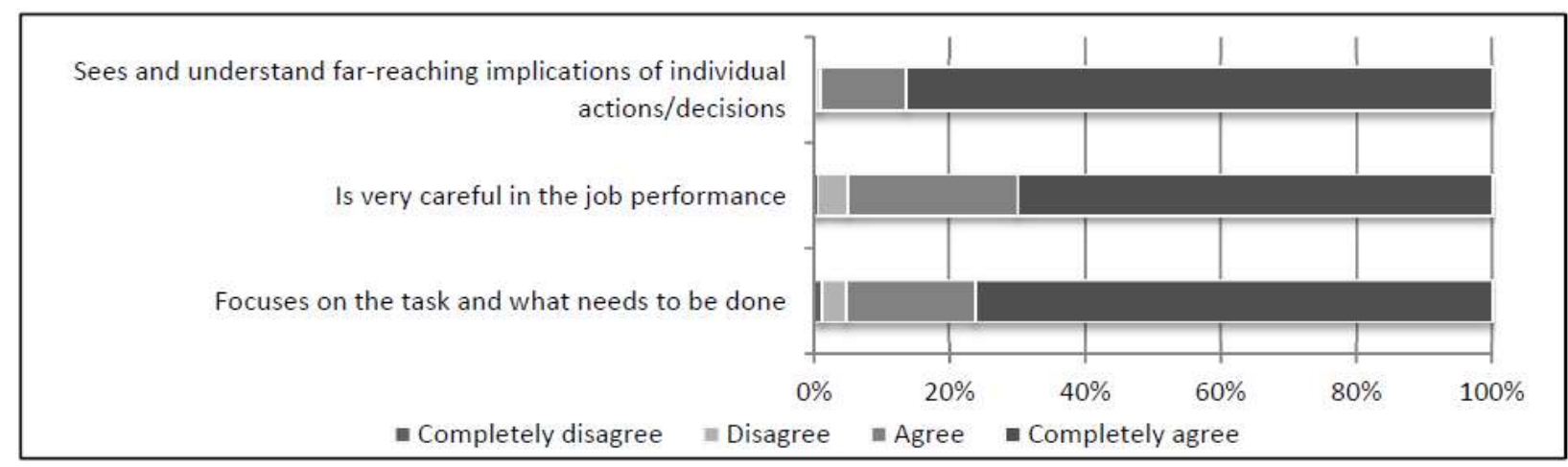

Figure 2. Peer-evaluation results for the responsibility skill ( $\mathrm{n}=107$ students). 


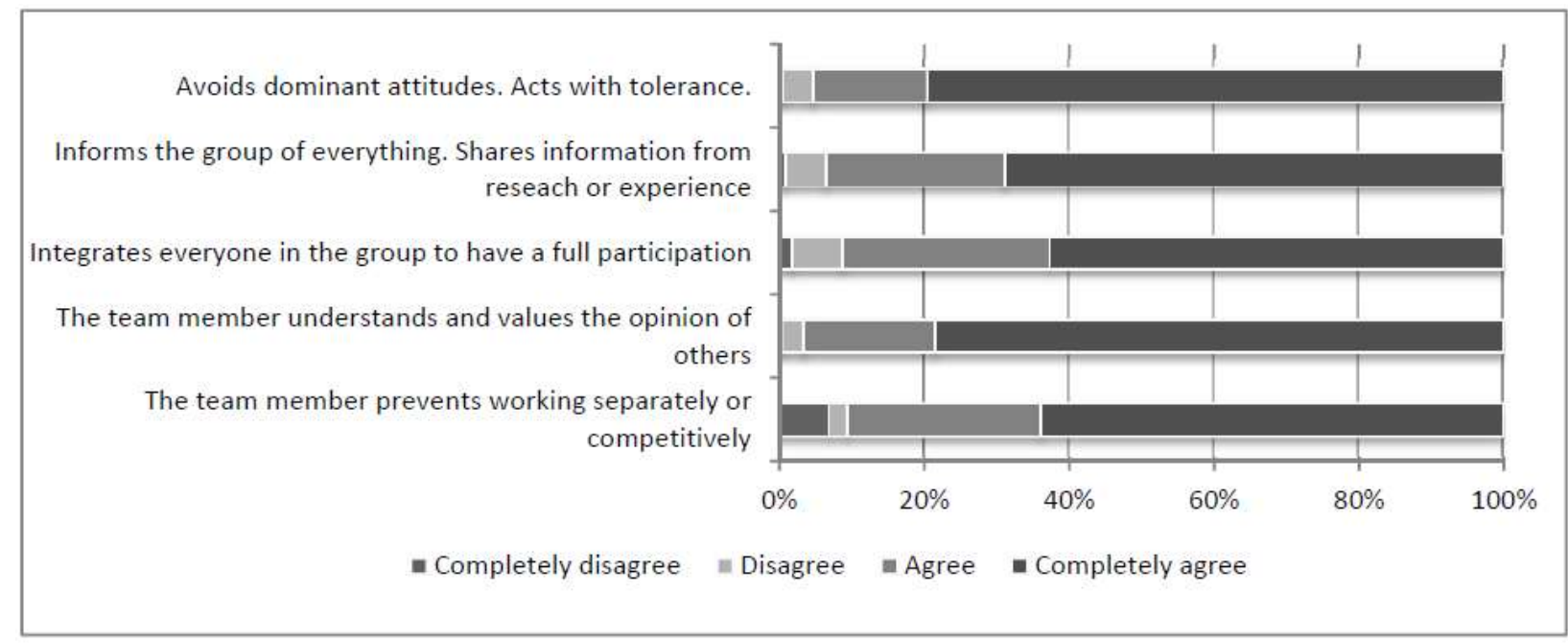

Figure 3. Peer-evaluation results for the team working skill ( $n=107$ students).

As shown, each template used contains between three and five items associated with the skill to be assessed. Students filled in these templates to assess their colleagues' competences and attitudes. For each item, they had to select an answer among "completely disagree", "disagree", "agree" and "completely agree". The items were drafted in order to associate answers to the perception of the skill development. For instance, choosing "completely agree" or "agree" answers means that the person who assess has a good perception of him/her peer skill development.

After analyzing the data, the first conclusion drawn is that the fellow students' perception was quite positive. Their attitudes and skills were evaluated positively, with few "completely disagree" answers. In fact, over 90\% are "agree" and "completely agree" in all items, being more than $50 \%$ "completely agree".

A good working atmosphere was detected by teachers in the classrooms involved in this experience. This could be one important reason to support these good results. Active learning methodologies used in those groups, encouraged the students' participation in their own learning process. Team working provided students the opportunity to strengthen the links between classmates, and also could improve their perception about their skills development.

Following the action-research methodology, we made a reflection after each of the experiences made. During these reflections, the results of a group or even of a particular student were analyzed in order to point out the strengths and weaknesses in their skills development. From this analyze, teachers could identify which skills must be encouraged in future learning activities or courses. This particular experience was carried out with freshmen. Results helped teachers to plan their actions in subsequent assignments or subjects. For example, oral and written communication seemed to have the worst results, so teachers had the information to know where the emphasis on the skill development had to be made.

In order to know students' opinions about this way of key skill assessment a questionnaire was proposed to them. Students were asked about several items related to the utility of making a key skill self-assessment and peer-assessment, its repercussions in their learning process and the need of reflecting those assessments in their final mark (Figure 4). 


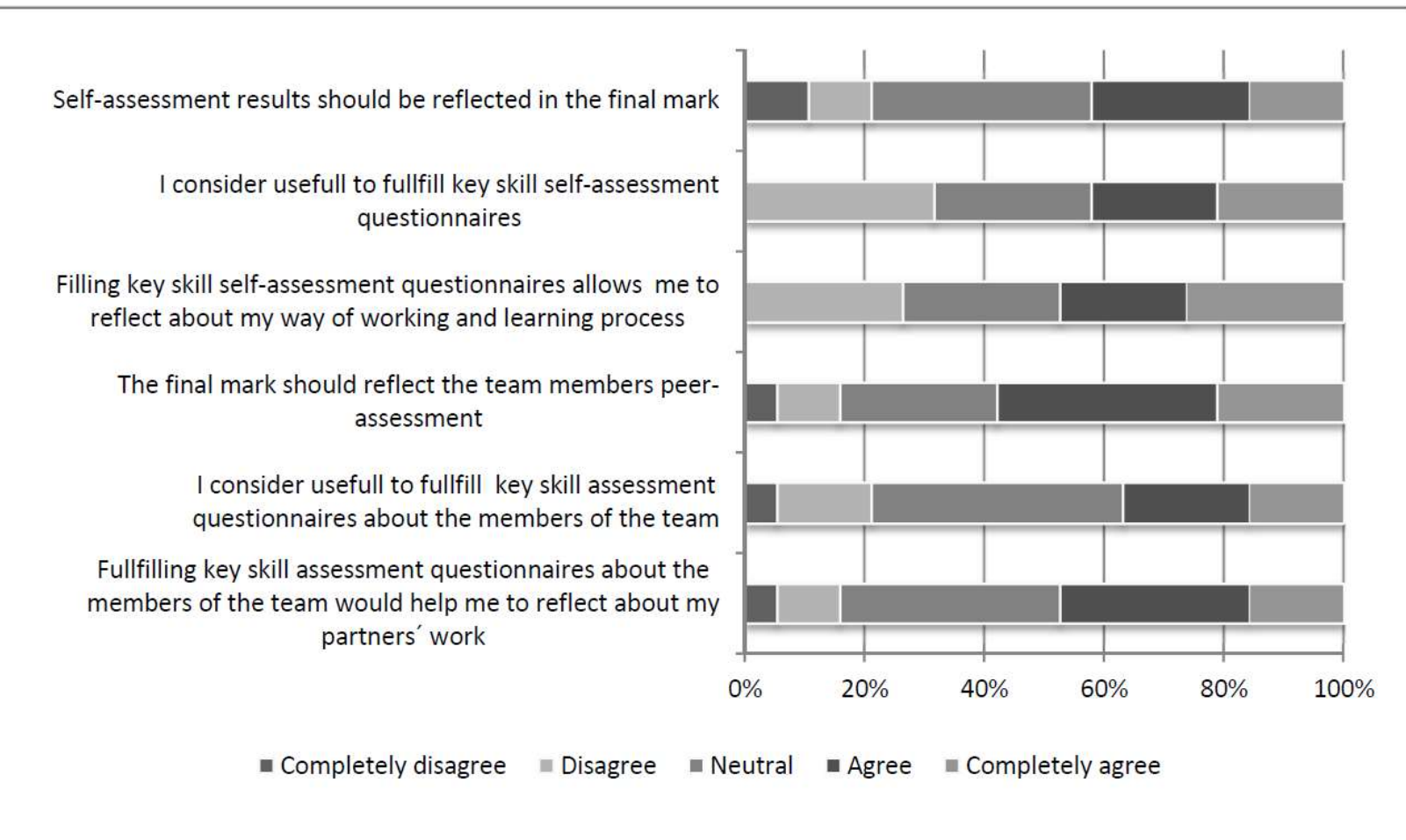

Figure 4. Survey results about key skill assessment ( $\mathrm{n}=104$ students)

In every item, negative answers ('completely disagree' or 'disagree'), were less than positive ones ('agree' or 'completely agree'). Although it seems that students are not sure about considering self-assessment results in the final mark, it must be mentioned that most of the students agree with reflecting their peer-assessment in the final mark.

\section{Conclusions}

In this paper, the work done by a group of professors interested in the development and evaluation of key skills in several degrees is exposed. Although it is acknowledged that students can learn key skills without being explicitly taught, it is important to assess key skill improvement, in order to make students aware of their key skill strengths and weaknesses.

One of the main contributions of this work is the elaboration of an actualized glossary of generic competences. A task of categorization and conceptualisation has been done in order to avoid the terminological ambiguity.

Having in mind which key skills should be developed in a degree, the coordination between the teachers of different courses and subjects in the same degree will be particularly necessary.

As a result of the process of reflection carried out during this experience, useful tools were developed which help teachers develop key skills in their students. Furthermore, assessment criteria are given, as well as grade descriptors and marking schemes of the competencies. Besides, some ideas to integrate guidance and feedback to the students are shown. 
The students' perception about their fellows' key skill development was quite positive. The students' participation in their own learning process created a good working atmosphere in the classrooms involved in this experience. From the survey results about key skill assessment done, it seems that the students felt comfortable with this way of assessment and they thought it could be useful for their apprenticeship.

For future works, the information management should be improved in order to simplify the readers' tasks. Working through an on-line campus would provide an automatic system for evaluation that will reduce teachers' workload. This would also improve the feedback to the students giving them updated information about their learning process. Similar experiences, from other teachers and universities, would generate a larger amount of data that would help to improve this guide within an action-research process.

\section{References}

Alles, M. A. (2005). Gestión por competencias - El diccionario. Buenos Aires: Granica.

Atlay, M., \& Harris, R. (2000). An institutional approach to developing students' transferable skills. Innovations in Education and Training International, 37(1), 76-84. http://dx.doi.org/10.1080/135580000362115

Australian Chamber of Commerce and Industry (ACCI), \& Business Council of Australia (BCA). (2002). Employability skills for the future (Government Report). Canberra: Department of Education, Science, and Training. http://hdl.voced.edu.au/10707/62282

Benito, A., Cruz. A., Bonsón, M., Enguita, C., \& Icarán, E. (2005). Nuevas claves para la docencia universitaria en el Espacio Europeo de Educación Superior. Madrid, Spain: Narcea.

Bennett, N., Dunne, E., \& Carre, C. (2000). Skills development in higher education and employment. London: Society for Research into Higher Education, Open University Press.

Blanco, Y., Terrón, M. J., \& García, M. J. (2007). Developing a key skills guide and assessment criteria for ICT degrees. In Actas da 4a Conferência de Engenharia "Engenharia' 2007 - Inovação e Desenvolvimento", Covilha, Portugal. http://hdl.handle.net/11268/3912

Boix Mansilla, V., \& Gardner, H. (2000). On disciplinary lenses and interdisciplinary work. In S. Wineburg \& P. Grossman (Eds.), Interdisciplinary curriculum challenges of implementation (pp. 161-198). New York: TC Press.

Boix Mansilla, V. (2005). Assessing student work at disciplinary crossroads. Change Magazine, 37(1), 14-21. http://dx.doi.org/10.3200/CHNG.37.1.14-21

Boix Mansilla, V. (2006). Quality assessment of interdisciplinary research: Toward empirically grounded validation criteria. Research Evaluation, 14(4), 17-29.

Boix Mansilla, V., \& Dawes Duraisingh, E. (2007). Targeted assessment of students' interdisciplinary work: An empirically grounded framework proposed. The Journal of Higher Education, 78(2), $215-237$. http://dx.doi.org/10.1353/jhe.2007.0008

Boix Mansilla, V., Dawes Duraisingh, E., Wolfe, C. R., \& Haynes, C. (2009). Targeted assessment rubric: An empirically grounded rubric for interdisciplinary writing. The Journal of Higher Education, 80(3), 334-353. http://dx.doi.org/10.1353/jhe.0.0044

Bologna Process. (2001, May 19). Towards the European Higher Education Area (Communiqué of the meeting of European Ministers in charge of Higher Education in Prague). Retrieved from www.ehea.info

Chapple, M. \& Tolley, H. (2000). Embedding the development of key skills within a traditional university. In S. Fallows \& C. Steven (Eds.), Integrating key skills in higher education: Employability, transferable skills and learning for life. London: Kogan Page.

Ellis, E., Klumpner, C., Leka, S., Philips, Z., Sharp, J., \& Wooldridge, K. (2004). Evaluation of key skills teaching: Student, teacher and employer perspectives. University of Nottingham, UK. Retrieved from http://www.nottingham.ac.uk 
European Credit Transfer and Accumulation System (ECTS). (2009). Retrieved from http://ec.europa.eu/education/

Fallows, S., \& Steven, C. (2000). Integrating key skills in higher education. Employability, transferable skills and learning for life. London: Kogan Page.

García, M. J., Terrón, M.J., \& Blanco, Y. (2007). Diseño y evaluación de competencias en las ingenierías de Telecomunicación. In IV Jornadas Internacionales de Innovación Universitaria, Métodos Docentes Afines al EEES, Villaviciosa de Odón, Madrid.

García, M. J., Fernández, L., Terrón, M.J., \& Blanco, Y. (2008). Métodos de evaluación para las competencias generales más demandadas en el mercado laboral. In C. Vaz de Carvalho, M. Llamas Nistal, \& R. Silveira (Eds.), TICAI 2008: TICs para a Aprendizagem da Engenharia (pp. 141-146). Porto, Portugal: Edições Politema; IEEE, Sociedade de Educação: Capítulos Espanhol e Portugués.

García, M. J., Fernández, L., Terrón, M. J., Blanco, Y. (2010). Desarrollo de recursos docentes para la evaluación de competencias genéricas. ReVisión, 3(3), 17-36.

González, J., \& Wagenaar, R. (Eds.). (2003). Tuning educational structures in Europe. Final Report- Phase 1. Bilbao, Spain: University of Deusto, University of Groningen.

Harvey, L., Moon, S., \& Geall, V. (1997). Graduates' work: Organisational change and students' attributes (Research Report). Birmingham, UK: Centre for Research into Quality.

Katzenbach, J. R. , \& Smith, D. K. (1993). The Wisdom of teams: Creating the high-performance organization. Boston, MA: Harvard Business School Press.

Key skills in the University of Salford. (n. d.). Retrieved from http://www.edu.salford.ac.uk/

Kohn, A. (2006). The trouble with rubrics. The English Journal, 95(4), 12-15. http://dx.doi.org/10.2307/30047080

Learreta, B. et al. (2006). La coordinación del profesorado ante las demandas del Espacio Europeo de Educación Superior: El caso de la Facultad de Ciencias de la Educación Física y Deporte en la Universidad Europea de Madrid. Madrid, Spain: UEM-ADEMAS Comunicación S.L.

Oliver, R. \& Sanz, M. (2007). The Bologna Process and health science education: Times are changing. Medical Education, 41(3), 309-317. http://dx.doi.org/10.1111/j.1365-2929.2006.02650.x

Orden ECl/332/2008, por la que se establecen los requisitos para la verificación de los títulos universitarios oficiales que habiliten para el ejercicio de la profesión de Médico [Order ECl/332/2008, establishing the requirements for the verification of recognized university degrees that qualify to practice medicine], BOE-A-2008-2674 (2008, February 13).

Poblete, M., \& García, A. (Coords.). (2007). Desarrollo de competencias y créditos transferibles. Experiencia multidisciplinar en el contexto universitario. Bilbao, Spain: Mensajero/ICE de la Universidad de Deusto.

Real Decreto 1393/2007, por el que se establece la ordenación de las enseñanzas universitarias oficiales [Royal Decree 1393/2007, establishing the regulation of recognized university education], BOE-A-2007-18770 (2007, October 29).

Real Decreto 55/2005, por el que se establece la estructura de las enseñanzas universitarias y se regulan los estudios universitarios oficiales de Grado [Royal Decree 55/2005, establishing the structure of university education and regulating recognized undergrtaduate degrees], BOE-A-2005-1255 (2005, January 21).

Rodríguez, R. M. (2003). Reaprender a enseñar. Una experiencia de formación para la mejora continua de la enseñanza universitaria. Revista Interuniversitaria de Formación del Profesorado, 17(2), 69-78.

Rychen, D. S., \& Salganik, L. H. (Eds.). (2001). Defining and selecting key competencies. Göttingen, Germany: Hogrefe \& Huber Publishers.

Rychen, D. S., \& Salganik, L. H. (Eds.). (2003). Key competencies for a successful life and a well-functioning society. Göttingen, Germany: Hogrefe \& Huber Publishers.

Rychen, D. S., Salganik, L. H., \& McLaughlin, M.E. (Eds.). (2003). Contributions to the second DeSeCo symposium. Neuchâtel, Switzerland: Swiss Federal Statistical Office.

Salganik, L. H., Rychen, D. S., Moser, U., \& Konstant, J. W. (1999). Projects on competencies in the OECD context: Analysis of theoretical and conceptual foundations. Neuchâtel, Switzerland: Swiss Federal Statistical Office.

Skills for Health. (n. d.). Developing skills in healthcare. Retrieved from http://www.skillsforhealth.org.uk 
Spencer, L. M., \& Spencer, S.M. (1993). Competence at work: Models for superior performance. New York, NY: John Willey \& Sons.

Terrón, M. J., Blanco, Y., Berenguer, F.J., \& Learreta, B. (2007). La coordinación del profesorado como necesidad en la construcción del EEES: Una experiencia en investigación-acción. Cuadernos de Innovación educativa en las enseñanzas técnicas universitarias, 1(2), 75-85. http://hdl.handle.net/11268/3921

Terrón, M. J., López-García, M. J., \& Blanco, Y. (2009a). Integrating key skills in information and communication technology degrees. Its assessment in the students. In Proceedings of the 2nd International Conference of Education, Research and Innovation (ICERI) (pp. 4628-4638). Madrid, Spain: IATED.

Terrón, M. J., García, M. J., \& Blanco, Y. (2009b). La responsabilidad en el aprendizaje. In A. Blanco (Coord.), Desarrollo y evaluación de competencias en educación superior (pp. 97-116). Madrid, Spain: Narcea.

Universidad Europea de Madrid. (2001). Informe Delphi - UEM: Evaluación de competencias en el alumnado de UECEES. Madrid, Spain: Instituto de Pedagogía y Psicología.

University of Sydney. (1997). Generic attributes of graduates of the University of Sydney (Academic Board Resolution). Retrieved from University of Sydney: http://sydney.edu.au/policies/default.aspx

University of Sydney. (2000). Strategic plan for teaching and learning, 2000-2004. Retrieved from http://www.eng.usyd.edu.au

University of Sydney. (2002a). Employability skills for the future: Comments from the University of Sydney. Retrieved from http://www.usyd.edu.au/su/ab

University of Sydney, (2002b). Plan for first year academic orientation and transition (Faculty of Rural Management, Orange Campus). Retrieved from http://www.itl.usyd.edu.au

University of Sydney, (2003a). School of Biological Sciences: Intermediate generic skills. Retrieved from http://bugs.bio.usyd.edu.au/

University of Sydney. (2003b). Institute for Teaching and Learning: Generic Attributes Project. Retrieved from http://www.itl.usyd.edu.au/

Villa, A., \& Poblete, M. (Dirs.). (2007). Aprendizaje basado en competencias: una propuesta para la evaluación de las competencias genéricas. Bilbao, Spain: Mensajero/ICE de la Universidad de Deusto.

Zabalza, M. A. (2000). El papel de los departamentos universitarios en la mejora de la calidad de la docencia. Revista Interuniversitaria de Formación del Profesorado, 38, 47-66.

\section{Acknowledgements}

This work was supported by the Education and Science Ministry, Ref. EA2008-0227. Thanks are expressed to Alexandra Lamas for correcting the English manuscript. 